\title{
BRPKM
}

Buletin Riset Psikologi dan Kesehatan Mental

http://e-journal.unair.ac.id/index.php/BRPKM

e-ISSN: 2776-1851

ARTIKEL PENELITIAN

\section{Hubungan Kepercayaan pada Pasangan terhadap Tingkat Stres pada Pria Dewasa Awal}

\author{
DIEVA ADELIA SALSABILA \& AFIF KURNIAWAN* \\ Fakultas Psikologi Universitas Airlangga
}

\begin{abstract}
ABSTRAK
Tujuan penelitian ini adalah untuk mengetahui hubungan kepercayaan pada pasangan terhadap tingkat stres pada pria dewasa awal. Penelitian ini menggunakan metode pendekatan kuantitatif dengan metode survei pada 223 orang pria berusia 18-25 tahun yang sedang menjalani hubungan berpacaran. Pengumpulan data menggunakan skala kepercayaan untuk mengukur tingkat kepercayaan pria dewasa awal pada pasangannya dan skala Perceived Stress Scale (PSS) untuk mengukur tingkat stres pria dewasa awal. Hasil analisis data dengan Pearson menunjukkan bahwa tidak terdapat hubungan yang signifikan antara kepercayaan pada pasangan dengan tingkat stres pada pria dewasa awal $(\mathrm{p}=0,131 ; \mathrm{r}=-0,101)$. Hubungan antara kepercayaan pada pasangan dengan tingkat stres bersifat negatif. Dikatakan bahwa semakin tinggi nilai kepercayaan pada pasangan, semakin rendah nilai tingkat stres, begitu juga sebaliknya.
\end{abstract}

Kata kunci: berpacaran, dewasa awal, kepercayaan, pria, tingkat stres.

\section{ABSTRACT}

This research aims to find out the correlation of trust in dating partner to the stress level of early adulthood men. This research uses a quantitative approach with a survey method on 223 men aged 1825 years who are in dating. Questionnaires in this research are scale of trust was used to measure early adulthood men trust level and Perceived Stress Scale (PSS) was used to measure early adulthood men stress level. The result of this research with Pearson showed that trust in partner does not significantly have a correlation to the stress level of early adulthood men $(p=0,131 ; r=-0,101)$. The relationship between the trust in partner and stress level is a negative. The higher value of trust in partner the lower value of stress level, and vice versa.

Keywords: dating, early adulthood, man, stress level, trust.

Buletin Penelitian Psikologi dan Kesehatan Mental (BRPKM), 2021, Vol. 1(1), 670-677

*Alamat korespondensi: Fakultas Psikologi Universitas Airlangga, Kampus B Universitas Airlangga Jalan Airlangga 4-6 Surabaya 60286. Surel: afif.kurniawan@psikologi.unair.ac.id

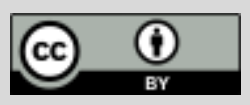

Naskah ini merupakan naskah dengan akses terbuka dibawah ketentuan the Creative Common Attribution License (CC-BY-4.0) (http://creativecommons.org/licenses/by/4.0), sehingga penggunaan, distribusi, reproduksi dalam media apapun atas artikel ini tidak dibatasi, selama sumber aslinya disitir dengan baik. 


\section{PEN D A H U L U A N}

Masa dewasa awal merupakan suatu masa transisi dari masa remaja yang masih menjalani kehidupan yang penuh ketergantungan ke masa dewasa yang lebih mandiri dan banyak menuntut rasa tanggung jawab. Dalam teori perkembangan psikososial yang dijelaskan oleh Erikson, masa young adulthood atau masa dewasa muda berkisar pada rentang usia 19-40 tahun (Crain, 2014). Pada masa ini, individu dituntut untuk menyesuaikan diri terhadap pola kehidupan yang baru serta peran sosial yang dilalui, seperti berperan dan bertanggung jawab atas tindakannya sendiri, mampu menerima kedudukan di dalam masyarakat, mencari pekerjaan, mulai terlibat di dalam hubungan sosial masyarakat serta menjalin hubungan dengan lawan jenis. Dalam menjalani kehidupan, individu pada masa dewasa awal sangat penting untuk menyelesaikan tugas perkembangannya, agar individu dapat mengarahkan dirinya pada kebahagiaan dan keberhasilan dalam menjalankan tugas perkembangan selanjutnya (Santrock, 2012).

Erikson mengungkapkan bahwa pada masa dewasa awal ini terdapat krisis perkembangan yang disebut intimacy vs isolation, yaitu masa di mana individu akan mulai membangun relasi yang dekat dengan orang lain terutama pada lawan jenis, baik itu sebagai pasangan maupun sebagai sahabat (Miller, 2011). Dengan tugas perkembangan tahap ini, individu yang telah memiliki identitas personal yang kuat setelah dikembangkan pada tahap sebelumnya akan dapat lebih siap dalam membangun hubungan yang intim dengan orang lain dan dapat mempertahankan hubungan dengan baik, namun ketika upaya individu gagal membangun hubungan yang intim tersebut, maka yang terjadi adalah individu tersebut kecenderungan merasakan sebuah situasi keterasingan dan terisolasi (Miller, 2011).

Pada pria dewasa awal, terdapat beberapa hal penting yang menjadi poin utama terkait perkembangan peran pria pada masa dewasa awal ini yaitu adanya tuntutan besar untuk melakukan perannya sebagai pria seperti menjadi pencari nafkah, sebagai pemimpin dalam rumah tangga, dan menjadi ayah. Terdapat tiga hal di mana peran pria dapat menyebabkan tekanan yang cukup besar, yaitu: (1) Kesehatan, karena peran pria memiliki tingkat risiko yang lebih tinggi daripada wanita; (2) Hubungan pria-wanita, bahwa banyak yang memandang bahwa peran pria mendorong pria untuk merasa lebih dominan, lebih kuat, agresif dan dapat memanipulasi wanita; (3) Hubungan sesama pria, karena peran pria lebih menekankan persaingan daripada kerja sama sehingga membuat hubungan emosional sesama gender yang kurang baik (Santrock, 2012). Tekanan-tekanan yang terus-menerus dirasakan oleh pria tersebut dapat memicu munculnya stres. Stres itu sendiri merupakan ketegangan emosional atau fisik yang berasal dari hasil interaksi dengan orang lain atau dengan lingkungan tertentu, di mana peristiwa stres dinilai oleh individu sebagai suatu hal yang mengancam dan melampaui sumber daya coping-nya (Biggs dkk., 2017).

Nasrani dan Purnawati (2012) menjelaskan bahwa terdapat perbedaan tingkat stres yang signifikan antara pria dan wanita pada 180 peserta yoga di Kota Denpasar, dengan prevalensi tingkat stres sebesar 40\%. Diketahui bahwa sebagian besar pria memiliki tingkat stres yang normal sebesar 95,1\%. sedangkan pada wanita sebesar 49,6\%. Hal ini didukung pula oleh penelitian Rahmayani dkk. (2019), terdapat perbedaan tingkat stres yang cukup signifikan antara pria dan wanita berdasarkan stresor pada 18 orang mahasiswa aktif Profesi Dokter Fakultas Kedokteran Universitas Andalas angkatan 2017 dengan hasil bahwa tingkat stres lebih tinggi dialami pada kelompok wanita sebesar 30,8\% sedangkan pada pria hanya sebesar $9,6 \%$.

Uniknya, pria memiliki lebih banyak beban tuntutan tugas perkembangan pada dewasa awal tetapi tingkat stres yang dirasakan cukup rendah apabila dibandingkan dengan tingkat stres yang dirasakan 
wanita. Meskipun banyak penelitian yang menyatakan bahwa wanita cenderung memiliki tingkat stres yang lebih tinggi daripada pria, tetapi realitanya pria lebih sulit dalam mengatasi stres yang mereka rasakan. Hal ini dikarenakan terdapat perbedaan antara pria dan wanita dalam mengekspresikan emosinya saat menghadapi stresor. Wanita lebih mudah dan lebih bebas dalam mengekspresikan emosinya ketika mengalami stres, seperti menangis atau bercerita pada teman dekatnya, sehingga wanita lebih mudah dalam meredakan stres yang dirasakan karena wanita akan paham apa yang harus dilakukan dalam mengatasi stresor tersebut. Sedangkan pada pria, umumnya mereka akan lebih memilih untuk menyimpan sendiri emosi yang dirasakan sehingga stres yang terus disimpan akan menumpuk dan suatu saat emosi tersebut akan semakin besar hingga meluapkannya dengan bentuk kemarahan dan keagresifan, hal tersebut akan membuat pria lebih sulit dalam mengatasi stresor karena pria tidak sepenuhnya memahami bagaimana mengatasi stresor tersebut (Mirowsky \& Ross, 1995).

Salah satu tugas perkembangan pria dewasa awal yang cukup disorot dalam penelitian ini yaitu terkait dengan relasi dengan lawan jenis di mana individu memiliki ketertarikan secara biologis terhadap lawan jenis dan memiliki motivasi yang besar untuk menghabiskan waktu bersama. Perasaan cinta tersebut diharapkan akan tercipta suatu hubungan yang lekat antara dirinya dengan lawan jenis tersebut, dan hal tersebut biasa disebut dengan pacaran. Rotter mendefinisikan kepercayaan sebagai suatu kecenderungan individu atas perasaan yakin bahwa kata atau perbuatan seseorang dapat dipercaya sehingga individu akan memenuhi kewajibannya dalam suatu hubungan timbal balik. (Rijt \& Buskens, 2006).

Ira dan Suryadi (2018) menjelaskan dalam penelitiannya, diketahui bahwa selain pengalaman masa kecil bersama orang tuanya, pengalaman yang kurang menyenangkan yang dialami individu dalam menjalin hubungan dengan lawan jenis juga mempengaruhi pembentukan kepercayaan. Lewicki \& Wiethoff (2006) menjelaskan terkait model perkembangan dan penghambatan kepercayaan pada intimate relationship merekomendasikan individu untuk percaya terhadap diri sendiri terlebih dahulu sebelum mempercayai lawan jenis dalam suatu hubungan yang intim. Terdapat beberapa komponen yang harus dipenuhi sehingga dapat mempengaruhi individu dalam membangun kepercayaan dalam suatu hubungan interpersonal. Komponen tersebut diantaranya adalah openness, sharing, acceptance, support, dan cooperative intentions (Johnson \& Johnson, 2012).

Sebagai individu yang memasuki usia dewasa awal, membangun hubungan yang intim dalam tujuan mencari pasangan hidup merupakan salah satu hal yang penting bagi pria dalam memenuhi tugas perkembangan di masa ini setelah mempersiapkan diri dalam membangun kemandirian secara finansial, kesiapan psikologis berupa kesiapan mental dan emosionalnya, serta kesiapan individu dalam hubungan interpersonal. Dalam membangun hubungan dengan lawan jenis, tentunya dibutuhkan adanya kepercayaan. Kepercayaan merupakan suatu hal yang penting bagi suatu individu dalam menjalani hubungan pacaran. Bagi pria di usia dewasa awal, menjalin hubungan pacaran tidak hanya sekedar sebagai keinginan untuk mencari seseorang yang dapat memberikannya kasih sayang, dukungan, dan perhatian saja, tetapi berpacaran menjadi salah satu jalan menuju hubungan yang penuh komitmen atau pernikahan. Dalam membangun kepercayaan pada pasangan, tentunya terdapat komponen yang harus dipenuhi agar dapat meningkatkan kepercayaan sekaligus mempertahankan kepercayaan tersebut pada pasangannya. Apabila kepercayaan yang diberikan pria kepada pasangannya menurun, hal tersebut memicu stres pada pria karena rasa takut apabila tidak mampu menyelesaikan tugas perkembangannya di masa dewasa awal.

Dengan adanya fenomena tingkat stres yang dirasakan oleh pria dalam tujuannya menyelesaikan tugas perkembangan untuk membangun hubungan dengan lawan jenis dikarenakan kepercayaan yang 
dimiliki serta masih kurangnya penelitian yang membahas tentang kepercayaan pada pasangan terhadap tingkat stres menjadi urgensi peneliti untuk melakukan penelitian mengenai apakah terdapat hubungan yang signifikan antara kepercayaan kepada pasangan terhadap tingkat stres pada pria dewasa awal.

\section{Desain Penelitian}

\section{E T ODE}

Pada penelitian ini, peneliti menggunakan pendekatan kuantitatif dengan prosedur pengambilan data secara survei serta menggunakan kuesioner sebagai alat dalam mengumpulkan data, guna mengetahui hubungan antara kepercayaan pada pasangan terhadap tingkat stres pada pria dewasa awal. Dalam studi kuantitatif survei yang dilakukan, penelitian ini dilakukan dengan menyebarkan kuesioner pada partisipan yang berisi alat ukur kepercayaan yang telah dirombak dan divalidasi oleh peneliti serta alat ukur Perceived Stress Scale (PSS) yang telah ditranslasi dan divalidasi oleh peneliti. Data dari responden tersebut selanjutnya dianalisis menggunakan teknik analisis korelasi Pearson.

\section{Partisipan}

Partisipan pada penelitian ini adalah pria berusia 18-25 tahun yang sedang menjalin hubungan berpacaran. Penentuan jumlah sampel partisipan dalam penelitian ini yaitu menggunakan metode nonprobability sampling karena populasi dalam penelitian ini yang tidak diketahui secara jelas jumlahnya dan dengan teknik accidental sampling agar peneliti dapat menggunakan sampel siapa saja yang muncul dan juga memenuhi kriteria partisipan. Penentuan besar sampel minimal pada penelitian ini menggunakan bantuan aplikasi $G^{*}$ Power 3.1.9.2 dengan statistical power sebesar 0,80 dan effect size sebesar 0,25. Jumlah partisipan dalam penelitian ini sebesar 223 orang $\left(\mathrm{M}_{\text {usia }}=20,2 ; \mathrm{SD}_{\text {usia }}=1,72\right)$ yang merupakan pria dewasa awal dengan rentang usia 18-25 tahun yang sedang menjalani hubungan berpacaran. Terkait dengan jangka waktu berpacaran, responden yang berpartisipasi pada penelitian ini sedang menjalani hubungan berpacaran kurang dari 1 tahun sebanyak 31,8\% (N=71), untuk yang sedang menjalani hubungan berpacaran dalam rentang waktu 1-3 tahun sebanyak $53,9 \%(\mathrm{~N}=120)$, dan yang sedang menjalani hubungan berpacaran lebih dari 3 tahun sebanyak 14,3\% $(\mathrm{N}=32)$. Sebelum pengisian kuesioner, partisipan diberikan informed consent sebagai bentuk persetujuan partisipan dalam mengikuti penelitian ini.

\section{Pengukuran}

Pada penelitian ini, pengukuran atau pengambilan data dilakukan menggunakan skala kepercayaan yang dirombak dan divalidasi oleh peneliti dari alat ukur yang digunakan pada penelitian sebelumnya berdasarkan dimensi kepercayaan oleh Johnson \& Johnson (2012) yang meliputi trusting dan trustworthy yang terdiri dari 34 item dan disajikan berupa skala likert dengan 4 pilihan jawaban (1="sangat tidak setuju", 4="sangat setuju"), serta alat ukur Perceived Stress Scale (PSS) yang telah ditranslasi dan divalidasi dari alat ukur yang digunakan pada penelitian sebelumnya berdasarkan dimensi tingkat stres oleh Cohen, dkk. (2013) yang meliputi unpredictable, uncontrollable, dan overload yang terdiri dari 14 item dan disajikan berupa skala likert dengan 5 pilihan jawaban (1="tidak pernah", $5=$ "sangat sering"). Teknik validitas yang digunakan dalam penelitian ini adalah content validity dan ditentukan melalui expert judgement. Reliabilitas kedua alat ukur yang digunakan dalam penelitian ini menggunakan teknik Cronbach Alpha, dengan nilai reliabilitas untuk skala kepercayaan sebesar 0,862 dan nilai reliabilitas untuk alat ukur Perceived Stress Scale (PSS) sebesar 0,321. 


\section{Analisis Data}

Pada penelitian ini, analisis data dilakukan dengan menggunakan teknik analisis korelasi Pearson dengan bantuan aplikasi IBM SPSS Statistics 25 for Windows.

\section{HAS IL PEN ELIT IAN}

\section{Uji Deskriptif}

Uji deskriptif dari penelitian ini menggunakan partisipan sebanyak 227 orang dengan nilai terendah pada variabel kepercayaan sebesar 81 dan variabel tingkat stres sebesar 17 sedangkan nilai tertinggi pada variabel kepercayaan sebesar 127 dan variabel tingkat stres sebesar 39. Nilai mean variabel kepercayaan sebesar 102,95 sedangkan untuk variabel tingkat stres sebesar 27,60. Berdasarkan norma kategorisasi, sebagian besar partisipan penelitian memiliki tingkat kepercayaan pada pasangan yang sedang, yaitu sebesar 60,5\% ( $\mathrm{N}=135)$, serta memiliki tingkat stres yang sedang, sebesar 69,1\% $(\mathrm{N}=154)$.

\section{Uji Hipotesis}

Setelah dilakukan uji asumsi dan uji asumsi dapat terpenuhi, maka peneliti melakukan uji hipotesis yaitu uji korelasi yang dilakukan untuk mengetahui arah dan kekuatan hubungan linear dari kedua variabel. Uji korelasi dilakukan menggunakan teknik analisis korelasi Pearson. Data yang diperoleh dalam penelitian ini menunjukkan $(\mathrm{r}(223)=-0,101 ; 95 \%$; $\mathrm{p}<0,131)$ sehingga diketahui bahwa tidak terdapat hubungan yang signifikan anatara variabel kepercayaan dan variabel tingkat stres. Kedua variabel dalam penelitian ini menunjukkan nilai korelasi yang negatif dengan arti bahwa hubungan kedua variabel yang berlawanan arah sehingga semakin tinggi nilai kepercayaan pada pasangan, maka semakin rendah nilai tingkat stres yang dirasakan, dan berlaku pula sebaliknya.

\section{I S K U S I}

Berdasarkan hasil dari analisis korelasi Pearson yang melihat hubungan kepercayaan terhadap tingkat stres, didapatkan hasil bahwa kepercayaan pada pasangan tidak berhubungan secara signifikan terhadap tingkat stres pada pria dewasa awal $(p=0,131 ; r=-0,101)$. Hal tersebut menunjukkan bahwa kepercayaan bukanlah hal yang cukup penting disorot yang dapat berkaitan dengan tingkat stres yang dirasakan oleh pria pada masa dewasa awal. Sejalan dengan yang disampaikan Baron dalam Syafitri (2018), hal tersebut mengindikasikan bahwa terdapat faktor lainnya yang dapat mempengaruhi tingkat stres dalam suatu hubungan berpacaran diantaranya yaitu masalah dari karakter kepribadian masingmasing pasangan, terdapat perbedaan yang menyebabkan konflik, perasaan bosan, serta perasaan cemburu.

Hasil norma kategorisasi penelitian pada data kepercayaan pada pasangan menunjukkan bahwa mayoritas subjek penelitian memiliki kepercayaan pada tingkat yang sedang. Seperti yang diungkapkan oleh Winayanti (2015), individu yang memiliki trust sedang menunjukkan bahwa mereka merasa tidak sepenuhnya yakin dengan maksud pasangannya, apakah pasangan mereka dapat mempercayainya, dan merasa tidak sepenuhnya yakin apakah mereka dapat dipercaya atau tidak oleh pasangannya. Meskipun terdapat rasa ragu tersebut, mereka masih merasa memiliki sebuah harapan akan kelangsungan hubungan mereka karena individu dengan tingkat trust yang sedang, di masa lalu pernah mengalami kekecewaan akibat kepercayaan yang mereka bangun dan mereka berikan tersebut telah disia-siakan oleh pasangannya sehingga kini mereka menjadi lebih berhati-hati dalam mempersepsikan perilaku dan 
motif positif yang ditunjukkan oleh pasangan mereka saat ini (Holmes \& Rempel dalam Winayanti, 2015).

Sedangkan untuk hasil norma kategorisasi penelitian pada data tingkat stres menunjukkan bahwa mayoritas subjek penelitian memiliki tingkat stres yang sedang. Banyak hal yang menjadi penyebab dari munculnya stres yang dirasakan individu, dan sumber stres tersebut sangat beragam dan bersifat individual sehingga hal-hal yang menyebabkan stres dapat bergantung pada persepsi masing-masing individu terhadap hal yang sedang dialami (Segal dkk. dalam Manita dkk., 2019). Pada pria dewasa awal, tingkat stres yang sedang dapat diartikan bahwa stres yang dirasakan sudah mulai mengganggu aktivitas sehari-hari disebabkan karena adanya pekerjaan yang belum selesai, beban tugas yang berlebih, dan/atau terdapat konflik yang terjadi dengan pasangan (Rasmun, 2004). Konflik yang terjadi dengan pasangan yang memicu terjadinya tingkat stres yang sedang disebabkan oleh banyak hal, salah satunya yaitu masalah dari kepribadian pasangan misalnya pasangan yang bersikap egois dan tidak pengertian, emosi pasangan yang tidak stabil, perilaku pasangan yang tidak dapat dipercaya, atau sikap pasangan yang suka berbohong (Baron dalam Syafitri, 2018). Hal-hal tersebut membuat pria merasa bingung akan apa yang terjadi dengan pasangan, takut dan merasa bersalah apabila ada kesalahan yang tidak disadari, hingga terbebani dengan apa yang harus dilakukan agar dapat meredakan konflik dengan pasangan dan mengakibatkan munculnya stres (Baron dalam Syafitri, 2018).

\section{S I M P U L A N}

Penelitian ini berfokus pada hubungan kepercayaan pada pasangan terhadap tingkat stres pada pria dewasa awal. Berdasarkan hasil analisis data penelitian yang telah dilakukan, bahwa kepercayaan pada pasangan tidak memiliki pengaruh yang signifikan terhadap tingkat stres pada pria dewasa awal. Hasil korelasi yang bersifat negatif antara kepercayaan pada pasangan dengan tingkat stres sehingga dapat diartikan bahwa semakin tinggi kepercayaan pada pasangan, maka semakin rendah tingkat stres, dan begitu juga sebaliknya.

Penelitian ini diharapkan dapat memberikan manfaat bagi penelitian selanjutnya dan juga bagi masyarakat umum, khususnya bagi individu dewasa awal yang sedang menjalani hubungan berpacaran. Dari hasil penelitian ini, peneliti menyarankan untuk penelitian selanjutnya dapat melakukan penelitian serupa tidak hanya pada pria namun juga pada wanita untuk membandingkan perbedaan antara kedua jenis kelamin tersebut, disarankan untuk mencari faktor lainnya yang dapat berhubungan dengan tingkat stres pria dalam suatu hubungan interpersonal selain kepercayaan agar dapat mengetahui faktor lain yang dapat berhubungan dengan tingkat stres di masa dewasa awal, serta disarankan untuk memilih dan menyesuaikan alat ukur yang akan digunakan dalam mengukur tingkat stres yang berkaitan dengan hubungan interpersonal sehingga benar-benar reliabel dalam mengukur variabel tingkat stres.

Dari hasil penelitian ini, peneliti menghasilkan saran bagi pria yang memiliki pasangan untuk mengomunikasikan segala perasaan yang mengganggu dan menjadi permasalahan bersama dengan pasangan agar kedua belah pihak dapat saling memahami, saling memberikan waktu dan ruang sementara di antara diri sendiri dengan pasangan untuk menenangkan diri serta introspeksi diri, juga lakukan bentuk coping stres yang positif untuk mereduksi perasaan dan emosi negatif yang sedang dirasakan. 


\section{U C A P A N T E R I MAKA S I H}

Dengan hormat, diucapkan terima kasih kepada Afif Kurniawan, M.Psi., Psikolog. selaku dosen pembimbing skripsi, H. Syamsul dan Hj. Purwati selaku kedua orang tua penulis, kedua kakak penulis, serta seluruh sahabat terdekat yang tidak dapat disebutkan satu persatu.

\section{DEKLARASI POTENSI TERJADINYA KONFLIK KEPENTINGAN}

Dieva Adelia Salsabila dan Afif Kurniawan tidak bekerja, menjadi konsultan, memiliki saham, atau menerima dana dari perusahaan atau organisasi manapun yang mungkin akan mengambil untung dari diterbitkannya naskah ini.

\section{PUST AKA ACUAN}

Biggs, A., Brough, P., \& Drummond, S. (2017). Lazarus and Folkman's Psychological Stress and Coping Theory. The Handbook of Stress and Health : A Guide to Research and Practice, First Edition., 351364.

Cohen, S., Kamarck, T., \& Mermelstein, R. (2013). Stress: A Global Measure of Perceived. 24(4), 385-396.

Crain, W. (2014). Theories of development: Concepts and applications (Sixth Edition). In Pearson New International Edition. https://doi.org/10.4324/9781315662473

Ira, \& Suryadi, D. (2018). GAMBARAN TRUST PADA DEWASA AWAL YANG MENGALAMI PERCERAIAN ORANGTUA DAN SEDANG BERPACARAN (STUDI KASUS DI JAKARTA). Jurnal Muara Ilmu Sosial, Humaniora, Dan Seni, 2(1), 378-385.

Johnson, D., \& Johnson, F. (2012). Joining together: Group theory and group skills. In Pearson New International Edition (Eleventh e). Pearson Education Limited. https://doi.org/10.1037/014685

Lewicki, R. J., \& Wiethoff, C. (2006). Trust, trust development, and trust repair. The Handbook of Conflict Resolution: Theory and Practice (2nd Ed)., http://ezproxy.net.ucf.edu/login?url=http://search.ebscohost.com/login.aspx?direct=true\&db=p syh\&AN=2006-12760-004\&site=ehost-live

Manita, E., Mawarpury, M., Khairani, M., \& Sari, K. (2019). Hubungan Stres dan Kesejahteraan (Wellbeing) dengan Moderasi Kebersyukuran. Gadjah Mada Journal of Psychology (GamaJoP), 5(2), 178. https://doi.org/10.22146/gamajop.50121

Miller, P. H. (2011). Theories of Developmental Psychology (Fifth Edition). Worth Publishers.

Mirowsky, J., \& Ross, C. E. (1995). Sex Differences in Distress: Real or Artifact? American Sociological Review, 60(3), 449. https://doi.org/10.2307/2096424

Nasrani, L., \& Purnawati, S. (2012). Perbedaan Tingkat Stres Antara Laki-laki dan Perempuan Pada Peserta Yoga di Kota Denpasar. 1-12.

Rahmayani, R. D., Liza, R. G., \& Syah, N. A. (2019). Gambaran Tingkat Stres Berdasarkan Stressor pada Mahasiswa Kedokteran Tahun Pertama Program Studi Profesi Dokter Fakultas Kedokteran Universitas Andalas Angkatan 2017. 8(1), 103-111.

Rasmun. (2004). Stress, Koping dan Adaptasi Teori dan Pohon Masalah Keperawatan. CV Sagung Seto.

Rijt, A. van de, \& Buskens, V. (2006). Trust in intimate relationships: The Increased Importance of

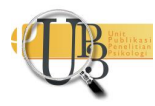


Embeddedness for Marriage in the United States. Rationality and Society, 18(2), 123-156. https://doi.org/10.1177/1043463106063319

Santrock, J. W. (2012). Life-Span Development.

Syafitri, A. (2018). Sumber Stres dan Perilaku Coping Individu Dewasa Muda dalam Hubungan Pacaran. Jurnal Sains Psikologi, 1(2), 1-14. http://journal2.um.ac.id/index.php/JSPsi/article/view/556

Winayanti, R. D. (2015). Hubungan Antara Trust Dengan Konflik Interpersonal Pada Dewasa Awal Yang Menjalani Hubungan Pacaran Jarak Jauh. 1-19. 